\title{
航空レーザー测距法による 大面積森林資源計测
}

末田達彦

\section{はじめに}

IPCC（2007）の予測によれば今世紀末まで に地球の平均気温は $1.1 〜 6.4^{\circ} \mathrm{C}$ 上昇する。しか し、これでは予測の幅が広すぎて、海面上昇・ 気象災害の増大·生態系の攪乱・食糧供給の不 安定化など、今後起こりうる問題に対し具体的 な対応策を取り得ないので、予測の精緻化が温 暖化対策上の重要な課題となっ ている。このように予測幅が広 いのには、1）温暖化を律する将 来の温室効果ガスの排出量を現 時点で決めることができない、2) スーパーコンピュータによる大 気・海洋物理過程の数值シミュ レーションという方法の特質、3) 森林破壊を主体とした土地利用 変化に起因する温室効果ガス収 支が未確定、という三つの理由 がある。最初の二つの問題は理 論的にも解決が難しいが、最後 の問題は理論的にも技術的にも 解決可能にもかかわらず、まだ 対応できていないのが現状であ る。小稿ではその背景、解決策 のひとつとして航空レーザー測 距法による精密な森林の炭素収 支計測法、およびその成果を紹 介したい。

\section{地球温暖化の二大要因}

器機観測による気象台の記録の多くは人口 集中などによるヒートアイランド現象の影響 を受けているとともに、過去 100 ～150年ほど しか遡れないので、時間的にも空間的にも地球 温暖化の実態を正しく反映していないことは 周知の通りである。そのため直接的な人為の影
図 1 樹木の年齢などによる過去千年の復元気温

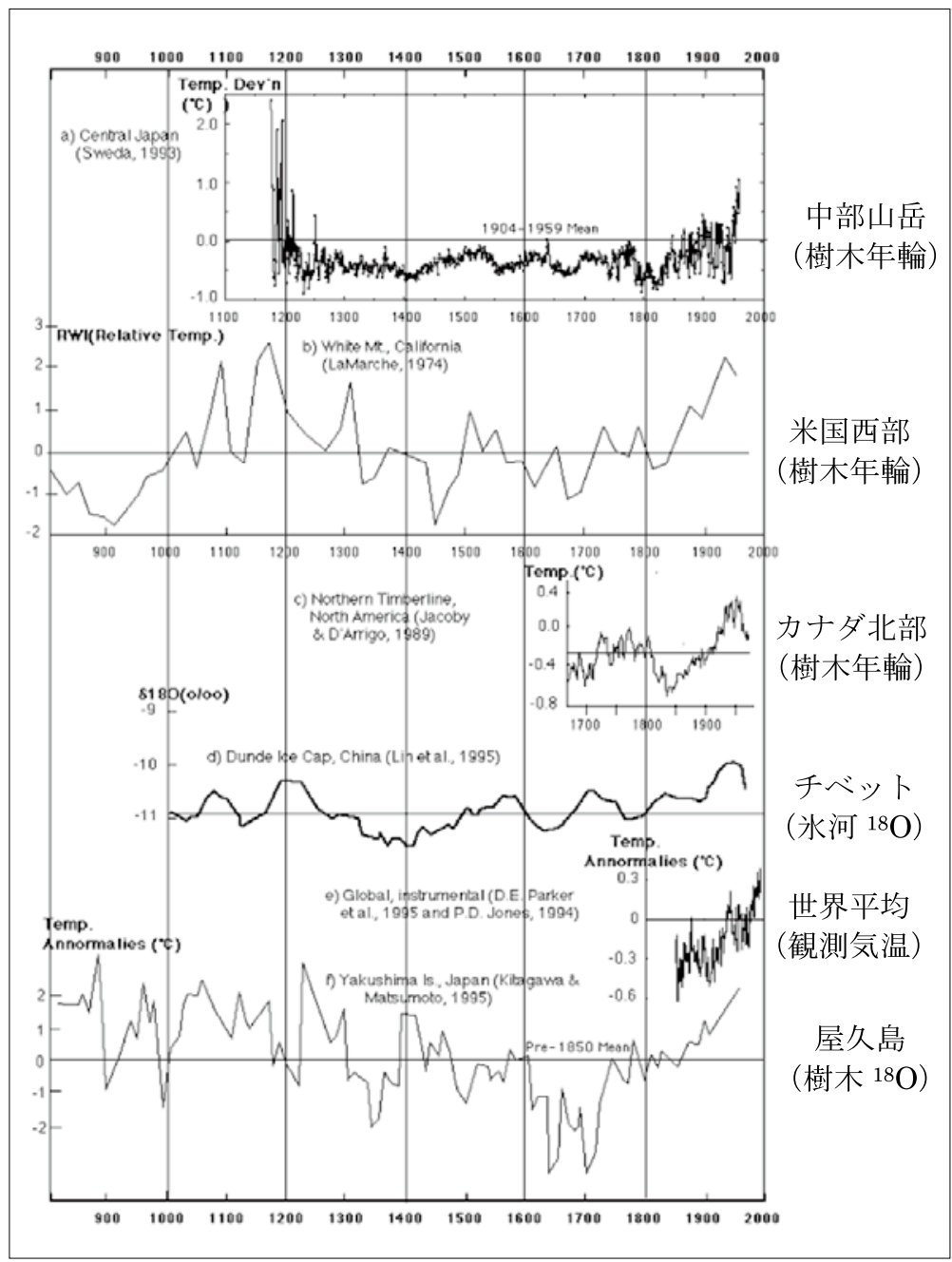


図2 化石燃料の消費と農地の開拓による温暖化

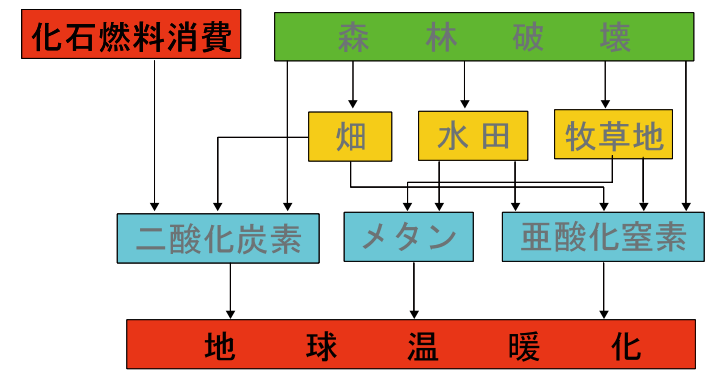

響がなくかつ長期的な気候復元には、樹木の 年輪や水床コアなどのプロキシーが使われる。 図 1 に数例を示したが、北半球の中高緯度では 200年ほど前から温暖化が始まったのが明らか である。この時期が石炭とは切っても切れない 関係にある産業革命の勃興期にあたることと、 現在では石油が二酸化炭素排出の主因となっ ていることなどから、産業革命以降の化石然料 消費が温暖化の主因であるかのようにいわれ ているが、これに負けず劣らず効いているのが 森林の消滅である。

産業革命の本質は、人力と畜力に限られてい た動力を機械力に置換えたことだが、機械力を 得るために大量の燃料を必要とする。元祖英国 における当初の蒸気機関の燃料は薪で、これが 石炭に代わったのは燃料としての木材が枯渴 したからでしかなかった (Kirby et al. 1956)。 さらに、機械力の獲得による生産性の飛躍的増 大は、先進国における人口の増大をもたらした。 英国では 1660 年に 700 万人の人口が産業革命を 終えた 1820 年には 1900 万人に増え、これに百 年余り遅れて産業革命に着手したわが国でも、
明治初期の 3,000 万人が現在の 1.2 億人へと四倍 増した。

人口の増加は食糧需要の増大を意味し、それ は森林の犠牲による農地拡大の必要性を意味 する。農地に変わり環流先を失った森林起原の 二酸化炭素は大気中に残留するが、森林地上部 とほほ同量の炭素を含有する土壤有機物につ いても同じことが言える。有機物は、森林を畑 にして好気的な条件で土壤を転耕すれば二酸 化炭素として、水田にして嫌気的に転耕すれば メタンとして大気に環流する。畜産業でもウ シを筆頭とする反煼動物はゲップとして大量 のメタンを放出する（Rifkin 1992）。かつての 化学的な污染による公害では一方的な被害者 だった農業も、温暖化については明らかな加害 者なのである（図2）。

かかる次第で、現在でこそ炭素排出の8割 近くを占める化石燃料消費が温暖化の主因と なっているが、第二次大戦以前には森林破壊と

\section{図3 人為による二酸化炭素の累積排出量 (Bolin 1986)}

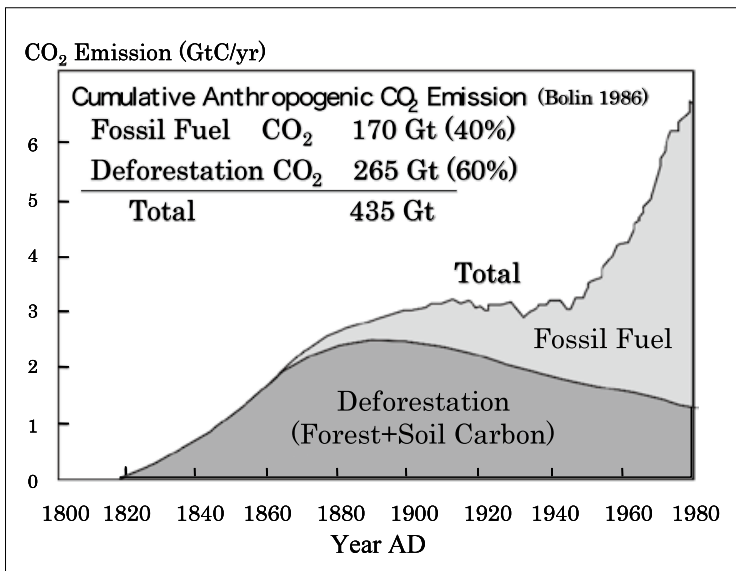


農地開発に起因する排出が化石燃料からの排 出を上回っていた。図3にBolin（1986）の推 定を示す。大まかな推定ながら 1986年の時点 でも、歴史的な累積排出量をとれば、森林破壊 に由来する排出が $265 \mathrm{GtC}$ (炭素換算ギガトン) と、化石燃料由来の $170 \mathrm{GtC}$ をきく上回って いる。

このように、第二次大戦以前は主として先進 国で起こっていた農地の開発とこれに伴う温 室効果ガスの排出が、戦後は途上国へと移行し た。後で述べるカリマンタンの荒廃泥炭湿地林 からの二酸化炭素排出も、米の自給を目指した 大規模農地開発に起因するものである。

\section{森林の炭素収支の不確定性}

現在、人為的な二酸化炭素の年間総排出量は 約7GtCである。IPCCの一次報告（1990）では、 うち $5.4 \mathrm{GtC}$ が化石燃料起源で、1.6 GtCが森林 破壊を主体とする土地利用変化によるとされ、 その行き先は大気中への残留が $3.4 \mathrm{GtC} 、$ 海洋 への吸収が $2.0 \mathrm{GtC} て ゙ 、$ 残る $1.6 \mathrm{GtC}$ が不明、す なわち所謂 missing sinkとされていた。二次報 告 (IPCC 1995) では、総排出量が7.1 GtCに増 えるとともに、吸収側では不明が $1.3 \mathrm{GtC}$ 残る が $0.5 \mathrm{GtC}$ が北半球の森林による吸収などと特 定され、 missing sink解消の方向に向かうかに 見えたが、最新の四次報告（IPCC 2007）では 森林や土地利用に関わる収支は、排出側も吸収 側も『不明』へと後退した。

\section{PROFILE}

末田達彦

(すえだ たつお)

愛媛大学農学部生物資源学科森林資

源学教授

専門 : 森林資源計測学

生産から消費に至る全過程が商取引として 記録に残る化石燃料からの排出量が明確なの に対し、森林の炭素収支に掴みどころがない 最大の理由は、不定形で細かな単位が輻輳し た陸上生態系の多様性と複雑さにある（図4）。 しかも森林は空気や水のように自然に混じり あって均質化するわけでもないので、正確だが 極めて限られた範囲の測定を広域に拡げるわ けにもゆかず、正確な值を出すためにはすべて を測らざるを得ないが、そうするには世界の森 林が広すぎるのが問題である。

また森林の炭素収支は、異なる二時点におけ る炭素蓄積の差として求めるが、森林の複雑さ

図4 パッチワークのように複雑な森林

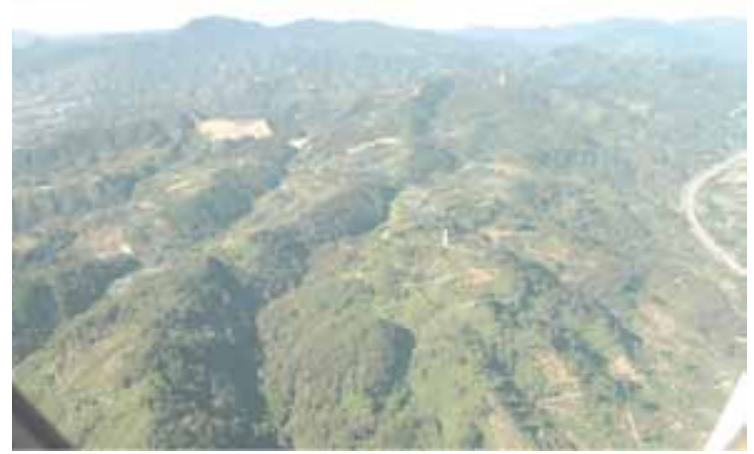




\section{図5＼cjkstart同じFAOによるさまざまな森林面積推定（Lomborg 2001）}

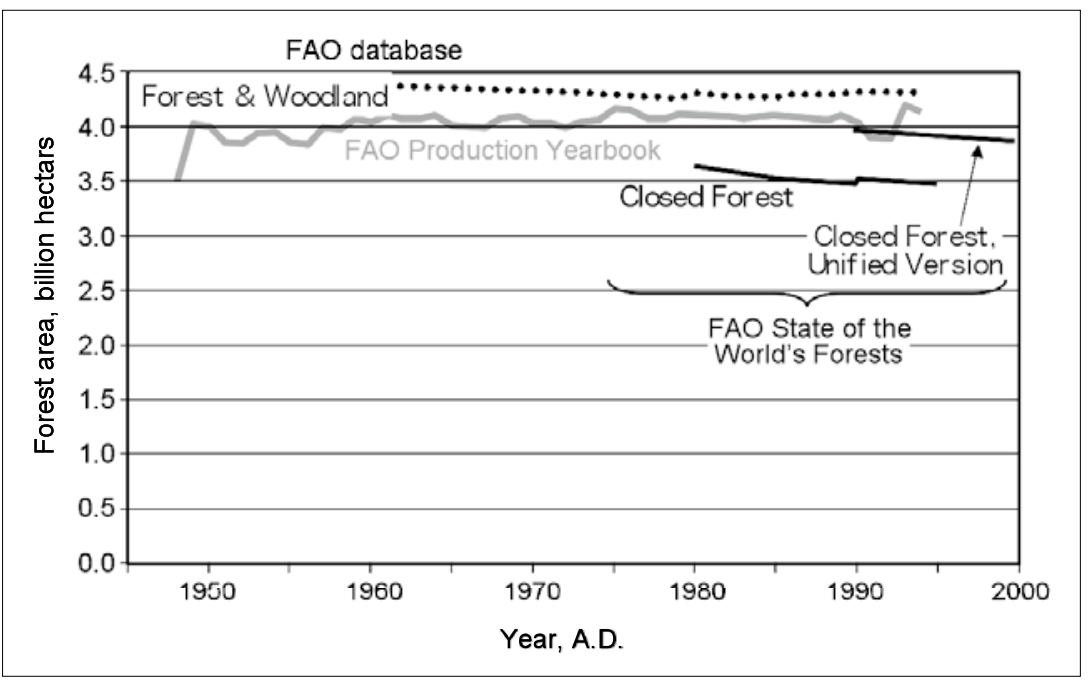

\section{図6＼cjkstart陸上生態系の炭素蓄積推定さまざま}

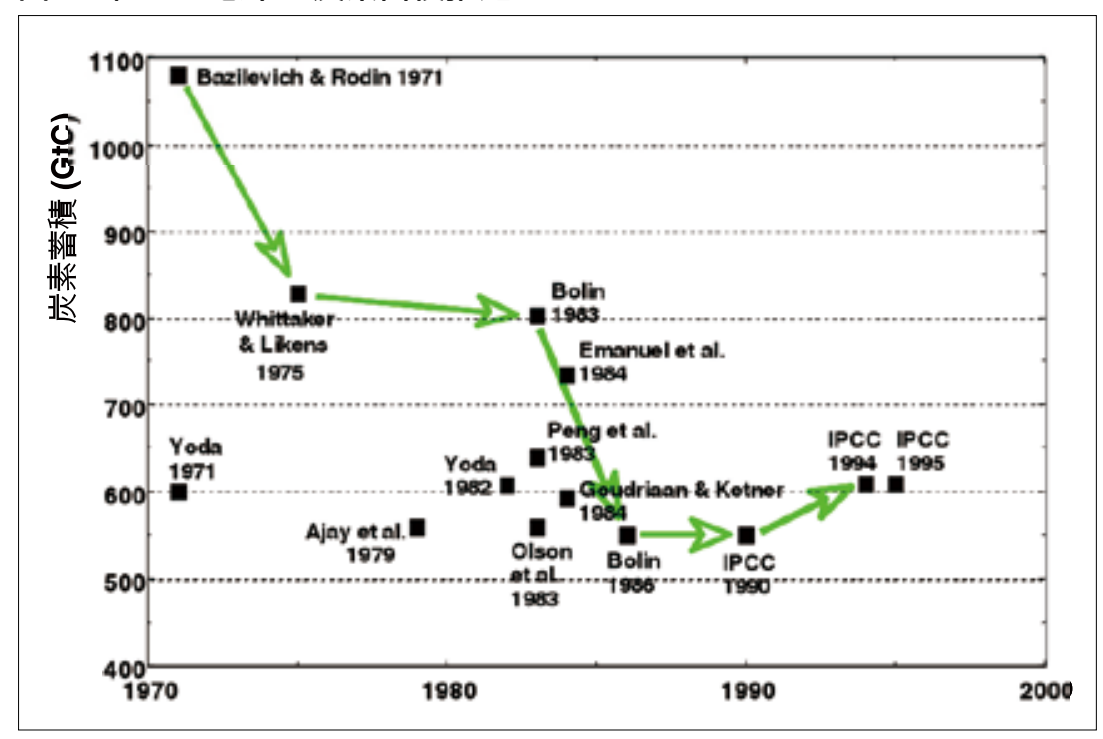

ら上限44億ヘクタール弱 まで、日本の国土面積の 30 倍近い食違いがある。

この食違いには定義に より集計值が変わるとい う事情もあるが、面積でさ えこの体ゆえ、さらに複雑 な要因が絡むバイオマス や炭素蓄積量の不確定性 は推して知るべしである。 今や 30 年ほど前のことで あるが『今日の世界の森 林統計の大半は憶測に毛 が生えた程度のものでし かない。(Westoby 1989) と掲破した人物がいる。極 論とはいえ実態に近い。

世界の陸上生態系炭素 蓄積の推定を時系列とし て図6に示した。大は 1.1 兆 $\mathrm{GtC}$ 弱から小は 5,500 億 $\mathrm{GtC}$ まで、学者や学術団体 により倍の開きがある。大 学演習林に扮ける本学の
故にこの蓄積すら正確な值が出せていない。そ れどころか蓄積推定の基礎をなす森林面積す らまともに把握できているとは言い難いのが 現状である。図5に世界の森林面積の推計を示 したが、FAOという同じ国連機関が出した統 計にもかかわらず、下限35億へクタール弱か
森林計測学実習では、1ヘクタールに満たない プロットのバイオマスを実測させたうえ、これ に森林面積を乗じて世界の森林炭素蓄積を推 定させているが、毎年 $5 千$ 億 -1 兆 $\mathrm{GtC}$ の間に 収まり、初学者と大学者の差は見えてこない。 


\section{リモートセンシングによる バイオマス推定}

広域にわたる森林蓄積推計の不正確さは、衛 星画像やその解析による地表情報の解読が進 歩した現在でもさほど変わっていない。図7に 示したLANDSATなどの衛星画像は広域にわ たり森林の存否を確認するには極めて便利で 有効な手段であるが、バイオマス量の測定とな ると難点が多い。というのは、森林のバイオマ 又量を決める二大要因は、樹高と立木密度（単 位面積あたりの立木本数）であるが、反射光の スペクトル特性で森林を測る衛星画像解析で は、原理的に樹高の測定が不可能だからである。 立木密度の測定は論理的には可能だが、太陽高 度、衛星の俯瞰角、森林表面のテクスチャー、 下層植生の種類と有無などによりスペクトル 特性が大きく変動するので、信頼性の高いデー 夕を得るのは難しいのが現状である。

\section{図7四国西部の衛星画像（戎）}

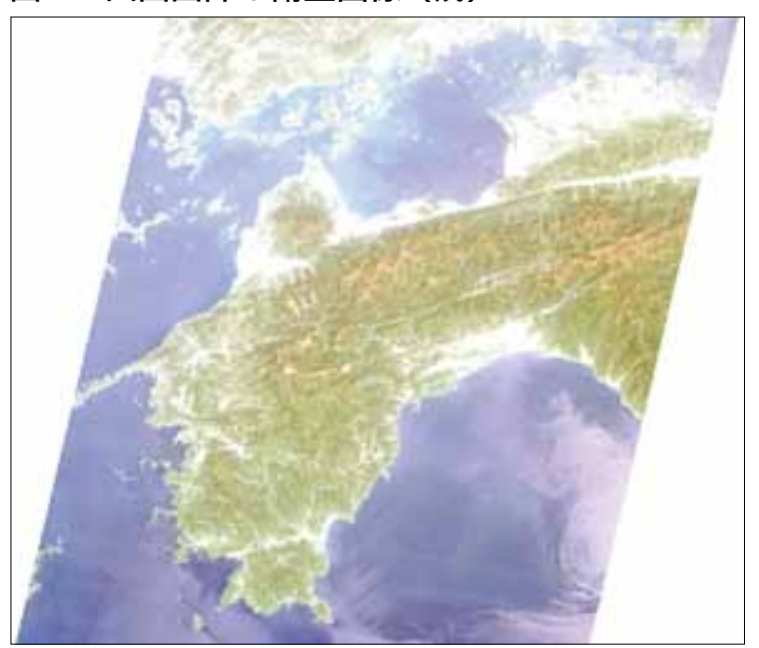

これら衛星画像や航空写真にかわる新しい リモートセンシングの方法として 30 年ほど前 に現れたのが航空レーザー測距法で、この方法 では上空から地表の事物の高さを正確に測る ことができる。基本的には地形測量の技術とし て進化してきたもので、現在でもその利用の主 流は地上の測量が困難な遠隔地や山岳地域の 精密測量である。航空測量という方法の特質上、 地形測量においても地表を覆う樹木や植生も 測定の対象に入ってくるが、これら植生データ は単なるゴミとして捨てられている。ところが 前述のように、森林の蓄積やバイオマスは植生 の高さによって決まると言っても過言ではな く、これを正確に測定できるということは、衛 星画像や航空写真では難しい森林蓄積の広域 精密推定が可能になったということである。

\section{航空レーザー測距法による 森林蓄積の計測}

航空レーザー測距法ではGPS（Global Positioning System) で捕捉した航空機の位置 と、これに搭載したレーザー測距儀から下方に 照射したレーザー光線が地面や木の葉などで 反射して帰るまでの時間から、地表の事物の三 次元座標を決める。この測距儀には、航跡に沿 い航空機の直下だけを測る『直下型』と、左 右に振って面的な測定が可能な『走查型』の 二種類があり（図8)、そのいずれでも森林を 測った場合には（図9a)、地面からと葉層から 
図8 直下型および走査型の航空レーザー測距

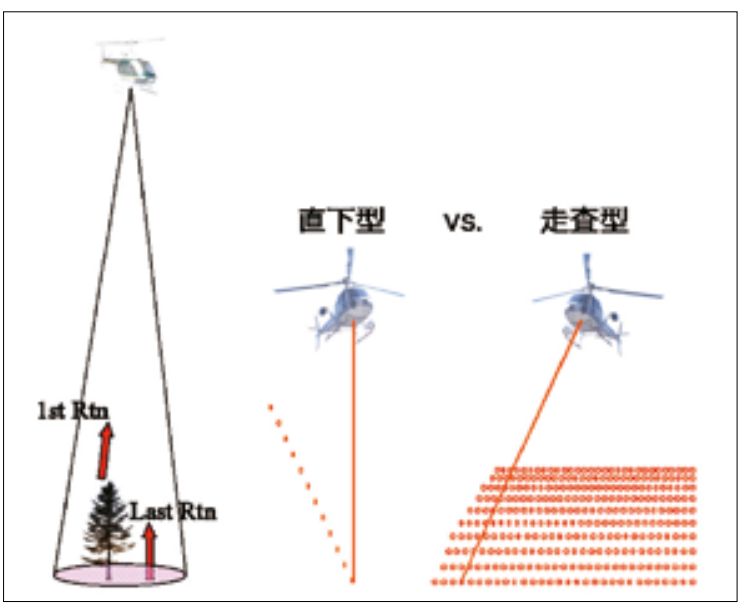

図9 航空レーザー測距法による森林のバイオマス測定

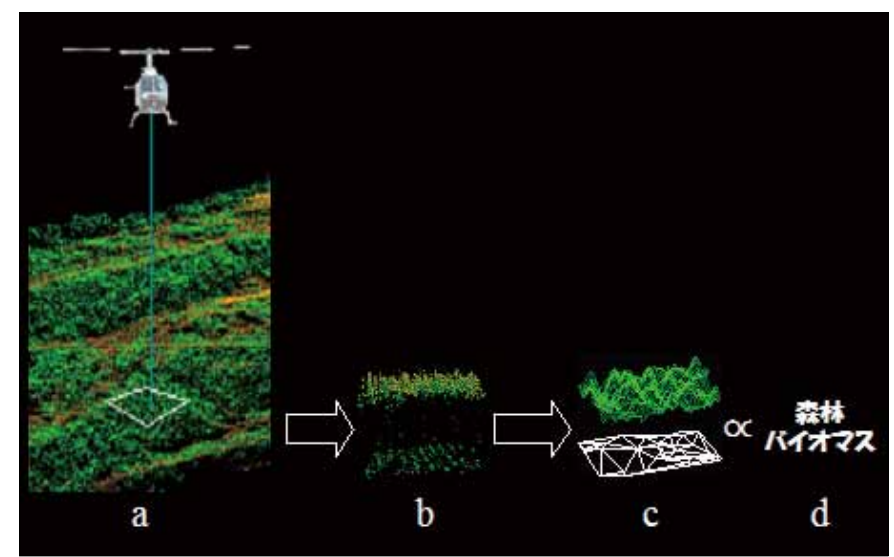

図 10 愛媛大学によるこれまでの航空レーザー測距

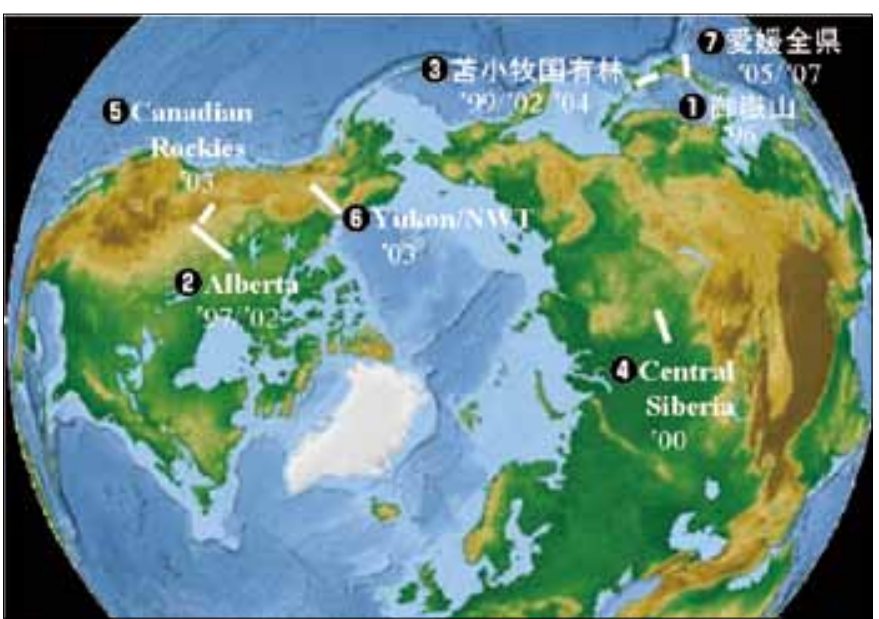

との反射が取れ（図9b)、それぞれの反射点を 繋ぐことによって地面と樹冠面とが決まる（図 9c)。これら上下二つの面で規定された森林の 縦断面積や空間体積は、対応部分の森林蓄積・ バイオマス・炭素蓄積とよく相関しているので (図9d)、地上での精密測定により前者に対す る後者の回帰を決めれば、広域にわたる森林の 蓄積を正確に推定することができる。また、森 林の生長量や炭素収支は異なる二時点におけ る蓄積の差として現れるので、同一対象 の時間差反復測定で求めることができ る。図10に、これまで私どもの研究室 が行ってきた広域森林測定の対象地と 測定年を示したが、このうち、1）京都 議定書にかかわる愛媛全県(7)の森林炭 素収支勘定、2）温暖化によるカナダ亜 寒带林(2)の植生移動の検出、3) 昨年か らボルネオとカナダ北部で始めた泥炭 湿地林の炭素収支計測を紹介する。

\section{愛媛県森林の炭素収支勘定}

わが国は、2008〜 2012年の京都議 定書第一約束期間までに1990年比で $6 \%$ の二酸化炭素排出削減義務を負っ ているが、政府は、議定書 3 条 4 項の 『ARD: Afforestation, Reforestation, Deforestation: 新規造林 - 再造林 - 森 林破壊』以外の追加的人為的活動、す なわち『森林管理による炭素吸収』で 
3.9\%を賄い、実質的な削減義務量を $2.1 \%$ とする方針で臨んでいる。この 炭素吸収量の記録·算定・報告にあ たり、IPCCの指針書 "Good Practice Guidance for Land Use, Land-Use Change and Forestry" (2003) は、透 明性·一貫性·比較可能性·完全性·正 確性·証明可能性·効率性の確保を強 く求めているが、炭素吸収量の算定に 林野庁が用いることにしている森林簿 の蓄積推定が過少なことは公然の秘密 で、上記 GPGを額面通り解釈するな ら IPCC の求める科学技術的な水準を 満たしうるとは言い難く、抜本的な改 善が望まれている。

そこで、航空レーザー測距法が森 林簿に代わるか、あるいはこれを補 完し経済的にも優れた森林計測の 手段であることを示すため、島嶼部 $221.7 \mathrm{~km}^{2}$ を除く愛媛全県を対象とし て2005年と 2007 年に反復計測を行い、 これら二時点における蓄積の差とし て全県の森林成長量と炭素収支を求 めた。予算の制約上、測定はNASA (National Aeronautics and Space Administration: 米国航空宇宙局）との共同研究 として同局の直下型レーザー測距儀を借り受け （図11）、全県を覆う $4 \mathrm{~km}$ 間隔の平行線（図 12 ) に沿って森林の存否と蓄積を測ったうえ、森林 部分の測線長と単位蓄積それぞれに $4 \mathrm{~km}$ の幅
図 11 NASAとの共同研
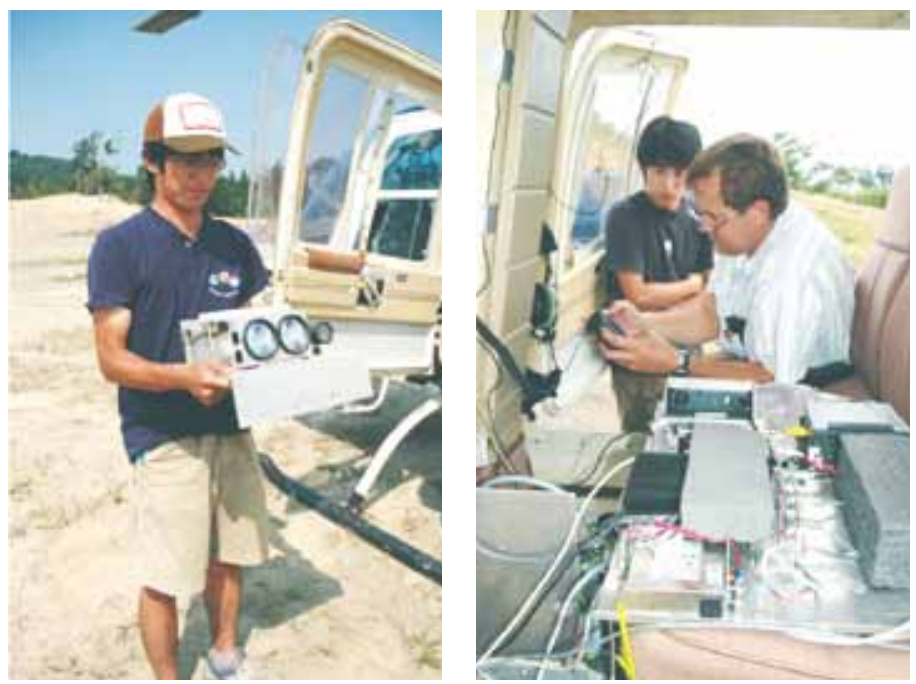

図 12 航空レーザー測距法による愛媛全県の森林炭素吸収量 の測定

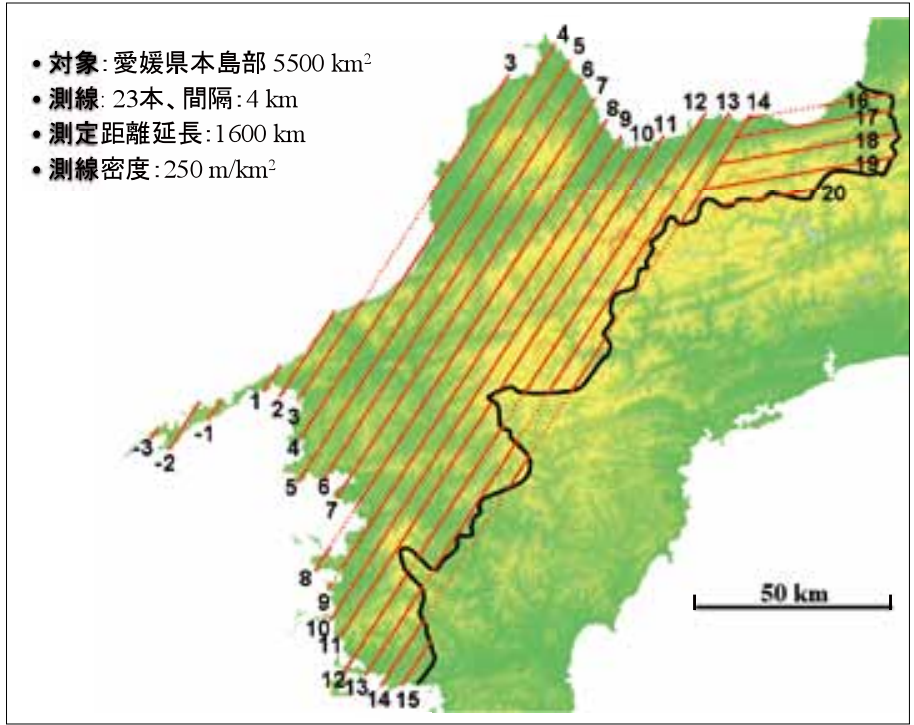

を乗じて全県の森林面積と蓄積を推定した。

その結果、測線の総延長 $1,358 \mathrm{~km}$ に幅 $4 \mathrm{~km}$ を 乗じた県本島部の面積は $5,432 \mathrm{~km}^{2}$ で、国土地 理院の值 $5,455 \mathrm{~km}^{2}$ と比べ $20 \mathrm{~km}^{2}$ (県土面積の 0.4\%）の過小推定になっていた。森林面積は 
図 13 森林（右）と化した往時の農地（左：原田 2007）

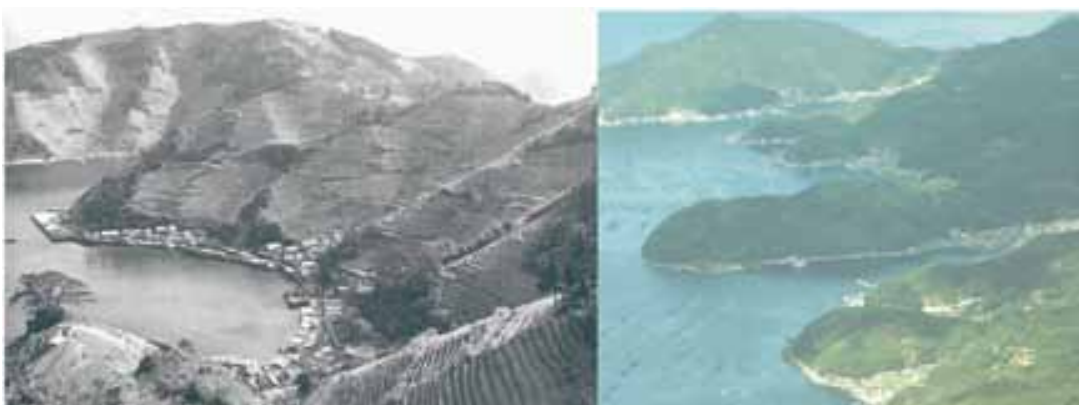

正が見込まれるため、最終 的な比較は多少動く可能性 があるが、上記森林面積蓄 積・炭素吸収量の矛盾が根 本的に解消されるほどでは ない。かねて森林簿の精度 には多方面から疑義が出さ れており、これに基づくわ $4,457 \mathrm{~km}^{2}$ で、県土の $81.7 \%$ となったが、上の県 土面積の推定結果から誤差は $1 \%$ 内外に収まっ ていると判断できる。この航空レーザーによる 森林面積に比べ、森林簿の值は $4,003 \mathrm{~km}^{2}$ と一 割ほど少ないが、それは、今は森林化した昔の 放棄農地など、実態は森林でも登記上は他の地 目になっているところなどが含まれていない ためである。図13に示したように愛媛県には このように森林化した放棄農地が多い。

森林蓄積は、森林簿の值 8,800 万 $\mathrm{m}^{3}$ の 1.6 倍、 1 億 4,300 万 $\mathrm{m}^{3}$ 強となり、予想通り森林簿が過 少推定になっていることが明らかになった。森 林成長量と炭素固定量は、それぞれ 147 万 $\mathrm{m}^{3}$ / 年と 49 万 $\mathrm{t} /$ 年で、ともに森林簿に基づく值の 8 割弱と、森林簿が炭素吸収量を過大に評価して いることが分った。蓄積が過小で成長量が過大 となる森林簿は、森林を若く評価しすぎている ということである。世間一般が若すぎるとして いる $30 〜 40$ 年の標準伐期齢にいまだ拘泥して いる林野庁自身の見解とはよく整合している が、わが国の森林の実態を捕らえているとは言 い難い。航空レーザーの推定にもまだ多少の補
が国の京都議定書森林炭素収支勘定には真剣 な見直しが必要と思われる。

\section{カナダ亜寒帯林の植生移動}

自然の植物は自らの生理・生態的特性にか なった気候条件下に生育しており、気候が変わ れば植生も徐々に変わる。温暖化による自然植 生の変化が予測されているが、自然植生の変化 は作物の適地の変化を示唆し、ひいては食糧供 給の不安定化を意味するので、その予測は森林 の炭素収支勘定より重要とも言える。しかし、 年々の変化は微々たるもので、かつ時間的にも 地域的にも跛行性が強いため、通常の小面積の 植生調査で検出することは不可能か、あるいは 検出できたとしてもそれがどの程度の広域的 普遍性を持つのかという保証に欠ける。しかし 植生の分布方向に沿い航空レーザー測距法で 広域にわたる植生量の変化を測れば、バイオマ スという量の変化として植生という質の変化 の前兆を捉えることが可能である。卑近な例で 言えば、抜け毛を定量的に観察すれば、ハゲと 
いう定性的な変化が現れる前にその前兆を捉 えることができるようなものである。

こうした観点から、温暖化による北米西部の 植生変化の検出を試みた。ロッキー山脈の東側 では、南から北に砂漠 $\Rightarrow$ プレーリー $\Rightarrow$ アス

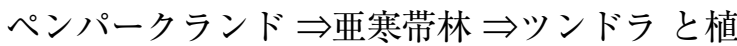
生が変わるが、このうちアスペンパークランド から亜寒帯中央部に至る南北 600 キロのトラン セクトを対象に 5 年間隔で二度の航空レーザー 測定を行い（図14）、測線沿いのバイオマス分 布を比較したところ、トランセクト南部 $1 / 3$ と 中央部 $1 / 3$ でそれぞれ平均 $1.2 \mathrm{t} / \mathrm{ha} 、 53.4 \mathrm{t} / \mathrm{ha}$ 減 少する一方、北部 $1 / 3$ では $3.3 \mathrm{t} / \mathrm{ha}$ 増加してい た。中央部におけるバイオマスの激減は大規模 な森林火災によるものであるが、森林火災の頻 発や大規模化自体、降水量の増加を凌ぐ気温の 上昇という温暖化の予測とよく整合している。 またトランセクト南部でのバイオマス減少と、 北部での増加は、温暖化により亜寒帯林が全体 として北に動くというカナダ北方森林研究所 の予測と一致している。

\section{図 14 カナダ亜寒帯林の航空レーザー測線}

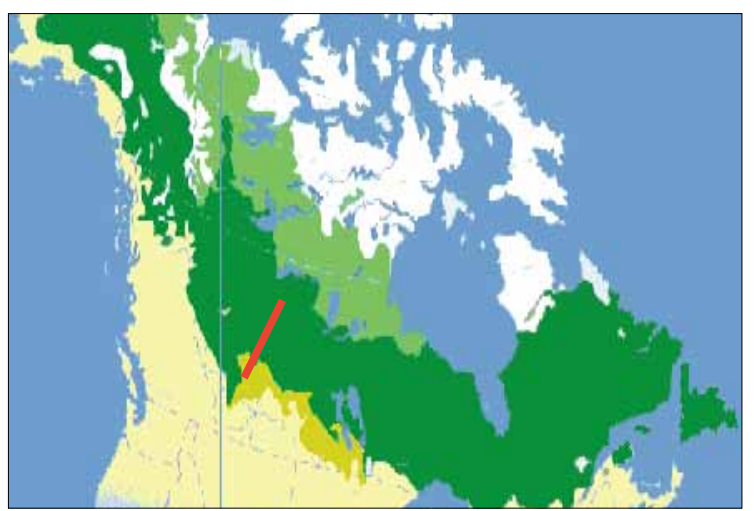

これはトランセクト一本の例に過ぎず、まだ 確定的なことは言えないが、特に今後の温暖化 が顕著と予測されている北米およびユーラシ ア大陸それぞれに、砂漠・草原・亜寒帯林・ツ ンドラ・氷雪地帯という南北の植生傾度を縦断 する $1,000 〜 2,000$ キロのトランセクトを数本入 れれば、植生変化により人類が深刻な不都合を 被る前に、その程度と速度を予測することがで きるものと考えている。なお、この植生移動の 結果はすでに学術月報で報告しているので（末 田 2004)、図表は割愛させて頂いた。

\section{温暖化にともなう泥炭湿地からの 炭素放出量の定量}

世界には高緯度と熱带地方を中心に3〜 4億 ヘクタールの泥炭湿地が分布し、総計500GtC ほどの炭素の蓄積があると言われている。高緯 度泥炭の主成分がミズゴケで、分布面積は広い が単位蓄積が比較的少ないのが特徵なのに対 し、熱帯では泥炭の主成分が木質で、分布面積 は少ないが単位蓄積が多く、とくにカリマンタ ンでは厚さ $10 \mathrm{~m}$ 越える泥炭層も稀ではない。 また、高緯度地方では温暖化にともなう永久凍 土の融解と好気分解、および森林火災の頻発に よる焼失で大量の炭素放出が起こると懸念さ れており、その量は今後 100 年間で $100 \mathrm{GtC}$ 程 度（Davidson \& Janssens 2006）と見積もられ ているが、これは世界の年間化石燃料消費の 18.5 年分に相当する。一方、熱帯では人口増加 
図 15 中央カリマンタンの水田開発跡地。左図の水路は排 水路、右図の前景は焼畑の延燃による火災跡地、背 景は回復途上の草地と湿地林。

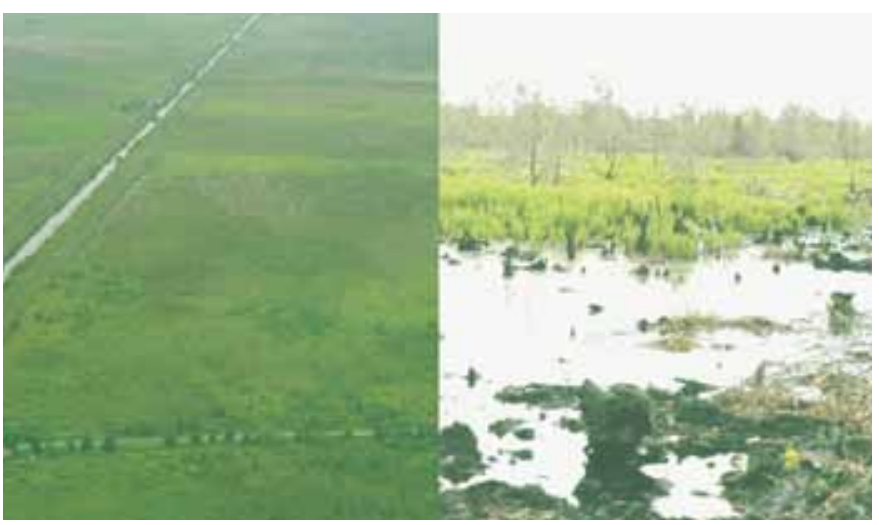

下部泥炭を包含した全生態系の炭素収 支を明らかにしようというものである。 研究対象地は、インドネシア中央カリマ ンタンの泥炭湿地林で、1990年代後半 に行われた大規模農地開発の跡地とそ の周辺の残存森林 100 万へクタールであ る。跡地というのは、水田開発を目論み 湿地林の排水のため4,000キロに及ぶ排 水路を掘削したものの、貧栄養かつ硫酸 酸性の泥炭土壤のため農業が成り立た ず大半が放棄されたままになっている

に対応した農地の開発で泥炭の消失と炭素の 放出が進行中で、東南アジア地域におけるそ の量は平均して年間360MtCほど (Page et al. 2010）と見積もられているが、気候条件により 大きく変動する。特にエルニーニョの影響が顕 著で、これが強く発現した1997年には泥炭の 好気分解と火災による焼失でインドネシア一 国からだけでも 0.81 ～2.57GtCの炭素が放出さ れた（Page et al. 2002）。この量は世界 の年間化石燃料消費の 13 ～40\%、京都 議定書によるわが国の排出削減義務量 の50〜 150倍にあたる。ちなみにこの 炭素放出量の推計にも大きな幅がある が、これも先に述べた衛星画像解析によ る推計の限界を示すものである。

現在私どもがカリマンタンで行って いる研究は、この推計の幅を大幅に狭め るとともに、成長・伐採・焼失を併せた 森林地上部と好気分解・焼失を併せた地

\section{図 16 航空レーザー測距法による泥炭湿地林の全炭素収支 計測}

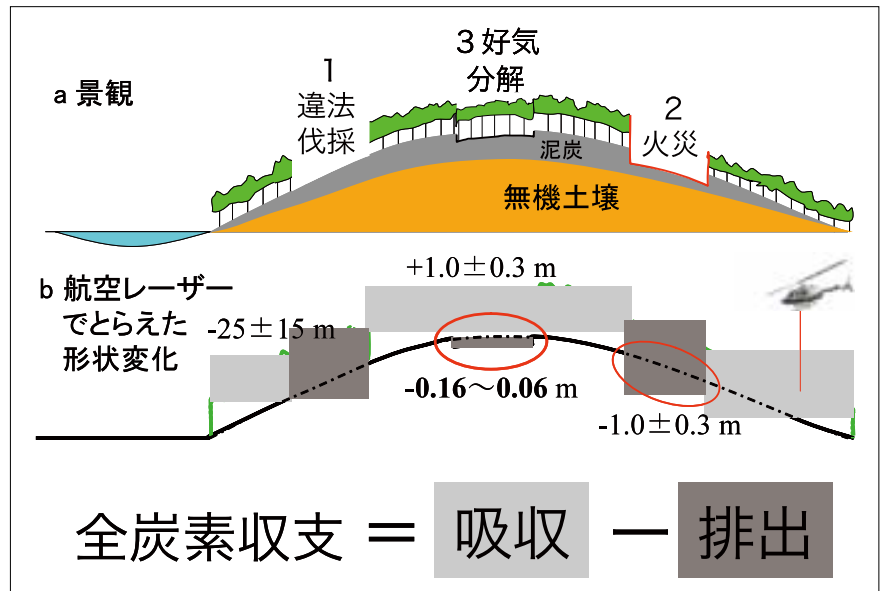


味はないが、地下部泥炭の炭素収支計測は世界 でも初めての試みである。これが可能なのは、 泥炭は植物の遺体で、量的な変化が形状の変化 として現れやすいからである。地上部・地下部 を含めた泥炭湿地林の炭素収支計測の概念を 図16に示した。

この熱帯泥炭の炭素収支と対比するため、本 年は同様の航空レーザー計測をカナダ北方の 泥炭湿地林で行う。カリマンタンにおける 3 年 間の泥炭の沈下量は焼失で $100 \pm 30 \mathrm{~cm}$ 、好気 分解で $20 \pm 5 \mathrm{~cm}$ ほどあるが、カナダ北方林で はいずれもその $1 / 5$ 程度の沈下量しか見达めな いので反復測定の期間を 7 年と多く取ってい る。カナダでの泥炭炭素収支が計測できれば、 航空レーザーによる森林計測に新しい地平が 開けたと言えるだろう。

\section{終わりに}

地球環境の恒常性に果たす森林の役割とそ の保全が声高に叫ばれているにもかかわらず、 熱帯林を中心に開発に歯止めがかからない理 由のひとつに、森林蓄積やその炭素収支が正確 に捉えられていないという現状がある。それゆ え世界の森林資源量とその変化の精密測定は、 温暖化の予測にも、その先にある低炭素社会の 構築にも不可欠な要件である。とくに泥炭湿地 林については、単に森林の消滅と炭素排出の増 加という問題にとどまらない側面がある。それ が高緯度地方のものであれ熱帯域のものであ
れ、泥炭は最終水期以降、過去 2 万年間に集積 した植物遺体であり、その消失はホモサピエン スの発生以来人類とともにあった自然の二酸 化炭素シンク機能の喪失という、未来に尾を引 く問題だからである。

\section{引用文献}

Bjorn Lomborg. 2001. The Skeptical EnvironmentalistMeasuring the Real State of the World. Cambridge University Press, Cambridge, xxiii+515pp.

B. Bolin. 1986. How Much CO2 Will Remain in the Atmosphere? In B. Bolin \& J. Doors (eds) The Greenhouse Effect, Climatic Change and Ecosystems. John Wiley \& Sons. 93-155.

E.A. Davidson \& I.A. Janssens. 2006. Temperature Sensitivity of Soil Carbon Decomposition and Feedbacks to Climate Change. Nature 440(9):165173.

IPCC. 2003. Good Practice Guidance for Land Use, Land-Use Change and Forestry. Inst. for Global Environmental Strategies, Hayama.

IPCC. 2007. Climate Change 2007: The Physical Science Basis. Contribution of Working Group I to the Forth Assessment Report of the Intergovernmental Panel on Climate Change [Solomon, S. et al. (eds.)] Cambridge University Press, Cambridge. 996pp.

J. Westoby. 1989. Introduction to World Forestry. Basil Blackwell, Oxford, $x+228 p p$.

S. Page, F. Siegert, J.O. Rieley, H-D.V. Boehm, A. Jaya and S.H. Limin. 2002. The Amount of Carbon Released from Peat and Forest Fires in Indonesian during 1997. Nature 420: 61-65.

S. Page, R. Wust and C. Banks. 2010. Past and Present Carbon Accumulation and Loss in Southeast Asian Peatland. PAGES NEWS 18(1): 25-26.

R.S. Kirby, S. Withington, A.B. Darling and F.R. Kilgour. 1956. Engineering in History. McGraw-Hill, New York, vii+530pp.

J. Rifkin. 1922. Beyond Beef. Thorsons, London, xiv+353pp.

末田達彦. 1996. 陸上植生の変動. 名古屋大学出版会『大気水 圏科学から見た地球温暖化』: 250-270.

末田達彦. 2004. 北極圈植生移動観測計画COCO GRANDE. 学術月報 57(5):426-51. 